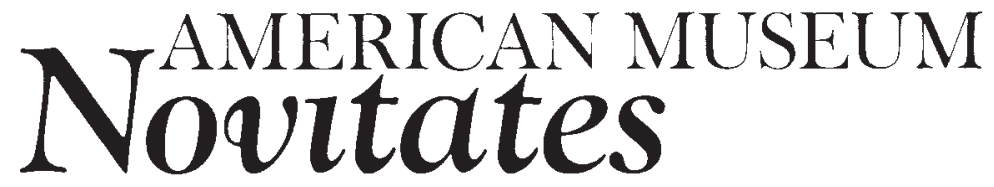

PUBLISHED BY THE AMERICAN MUSEUM OF NATURAL HISTORY CENTRAL PARK WEST AT 79TH STREET, NEW YORK, NY 10024 Number 3515, 7 pp., 2 figures, 1 table

May 17, 2006

\title{
The First Cretaceous Sclerogibbid Wasp (Hymenoptera: Sclerogibbidae)
}

\author{
MICHAEL S. ENGEL ${ }^{1}$ AND DAVID A. GRIMALDI ${ }^{2}$
}

\begin{abstract}
The first record of a fossil sclerogibbid wasp (Aculeata: Chrysidoidea) is reported. Sclerogibbodes embioleia, new genus and species, is described from a female preserved in Early Cretaceous (Neocomian) amber from Lebanon. The genus is sister to all other members of the Sclerogibbidae and is therefore placed in a monogeneric subfamily, Sclerogibbodinae, new subfamily. Sclerogibbids are obligate parasitoids of webspinners (order Embiodea = Embiidina, Embioptera), and thus the recovery of this lineage from Lebanese amber implies that webspinners were perhaps also present in the paleofauna.
\end{abstract}

\section{INTRODUCTION}

Wasps of the chrysidoid family Sclerogibbidae are obligate ectoparasitoids of webspinners (order Embiodea). Sclerogibbid females move adeptly through the silken tunnels of the webspinner's galleries and oviposit on the abdomen of the host. The newly emerged larva attaches itself to exposed membranes of its victim and feeds until the host is consumed. When feeding is complete, the larva detaches from the dead embiid and spins a cocoon near the host's carcass (Callan, 1939; Yokoyama and Tsuneyoshi, 1958; Ross, 2000). As it is presently understood, the family is rather poor in species (table 1) although many authors have hinted at an as yet unrecognized and undescribed diversity, with potentially dozens of new taxa awaiting description (e.g., Riek, 1970; Argaman, 1988, 1993; Ross, 2000). The scarcity of material, however, has generally impeded work on the family, and a new monographic treatment of sclerogibbids is desperately needed.

Herein we present the description of the first fossil of the family Sclerogibbidae, discovered

\footnotetext{
${ }^{1}$ Division of Invertebrate Zoology, American Museum of Natural History; Division of Entomology (Paleoentomology), Natural History Museum, and Department of Ecology and Evolutionary Biology, Dyche Hall, 1345 Jayhawk Boulevard, University of Kansas, Lawrence, Kansas 66045-7163 (msengel@ku.edu).

${ }^{2}$ Division of Invertebrate Zoology, American Museum of Natural History (grimaldi@amnh.org).
} 
TABLE 1

Current Hierarchical Classification of Family Sclerogibbidae

(The family is in need of a new monographic treatment)

\begin{tabular}{|c|c|c|}
\hline Taxon & Spp. (no.) & Distribution \\
\hline \multicolumn{3}{|l|}{ Family SCLEROGIBBIDAE Ashmead } \\
\hline \multicolumn{3}{|l|}{ Subfamily $\uparrow$ Sclerogibbodinae, n. subfam. } \\
\hline Genus $†$ Sclerogibbodes, n.gen. & 1 & Lebanese amber (Cretaceous) \\
\hline \multicolumn{3}{|l|}{ Subfamily Sclerogibbinae Ashmead } \\
\hline \multicolumn{3}{|l|}{$=$ Probethylinae Argaman (n. syn.) } \\
\hline \multicolumn{3}{|l|}{$=$ Caenosclerogibbinae Argaman (n. syn.) } \\
\hline \multicolumn{3}{|l|}{$=$ Tanynotini Argaman (n. syn.) } \\
\hline \multicolumn{3}{|l|}{$=$ Parasclerogibbini Argaman (n. syn.) } \\
\hline Genus Caenosclerogibba Yasumatsu & 1 & China, India, Japan. \\
\hline \multicolumn{3}{|l|}{ Sclerogibba?) } \\
\hline Genus Probethylus Ashmead & 4 & $\begin{array}{l}\text { Arizona (USA), Brazil, Mexico, } \\
\text { Trinidad. }\end{array}$ \\
\hline $\begin{array}{l}\text { Genus Parasclerogibba Hamann } \\
=\text { Mystrocnemis Kieffer }\end{array}$ & 1 & $\begin{array}{l}\text { India, Java, Madagascar, } \\
\text { Myanmar, Sri Lanka. }\end{array}$ \\
\hline \multicolumn{3}{|l|}{ Genus Sclerogibba Riggio and Stefani-Perez } \\
\hline \multicolumn{3}{|l|}{$=$ Tanynotus Cameron } \\
\hline \multicolumn{3}{|r|}{ India, Italy (Sardinia, Ustica), } \\
\hline \multicolumn{3}{|r|}{ Israel, Somalia, South Africa, } \\
\hline \multicolumn{3}{|r|}{ Sri Lanka, Togo, Tunisia, } \\
\hline \multicolumn{3}{|l|}{$=$ Poggiana Argaman (n. syn.) } \\
\hline \multicolumn{3}{|l|}{ Incertae sedis } \\
\hline "Sclerogibba" embiopterae Dodd & & Queensland (Australia) ${ }^{\mathrm{b}}$ \\
\hline
\end{tabular}

a Perhaps an introduction.

${ }^{\mathrm{b}}$ Riek (1970) also figures an enigmatic sclerogibbid from Australia.

in Neocomian amber from Lebanon. This fossil is significant not only as the earliest record of its family but also for its implications for understanding evolution within Sclerogibbidae, implying a minimum age for the family as well as for that of its host.

\section{SYSTEMATIC PALEONTOLOGY}

\section{FAMILY SCLEROGIBBIDAE ASHMEAD, 1902}

Sclerogibbodinae, new subfamily

Type Genus: Sclerogibbodes, new genus.

Diagnosis: Antenna 14-segmented; compound eyes comparatively large, with scattered minute setae, well separated in dorsal view from preoccipital ridge, separated by at least one-quarter of compound eye length (e.g., similar in this respect to Caenosclerogibba, although in this living genus the eyes are more reduced and even more distantly separated from the preoccipital ridge); ocelli present (difficult to discern among debris on head), median and lateral ocelli well developed; anterior head process strongly developed and projecting beyond lower tangent of compound eyes at least one-half of compound eye length (similar in this respect to Neoscleroggiba); preoccipital ridge carinate; head slightly longer than pronotum. Pronotum not tapering posteriorly in dorsal view, posterior margin distinctly wider than anterior margin (pronotum in extant females tapers posteriorly such that the anterior margin is typically slightly wider than the posterior margin); propleuron obscured in dorsal view by pronotum; female with wings completely developed; hind wing apparently without venation; forewing mostly obscured in ventral view by body and in dorsal view by fractures and debris in amber, only extreme anterior margin (i.e., C, Sc + R, pterostigma, basal portion of $\mathrm{r}-\mathrm{rs}$, and $\mathrm{R}$ anteriorly 
bordering marginal cell evident) visible from behind body in ventral view, marginal cell apparently long, extending slightly more than half the distance between pterostigma and forewing apex; procoxa apparently dorsal furrow weakly developed; profemora greatly expanded, ventral margin with thin lamella along outer margin; protibia not widened; only a single mesotibial spur evident (second may indeed be absent, or exceedingly small and difficult to discern); pretarsal claws with short, subapical tooth.

Comments: This subfamily is immediately recognizable for the retention of wings in females; females of Sclerogibbinae are apterous. The specimen is unfortunately dorsally obscured by fractures and debris posteriorly from the mesoscutum to the abdomen rendering observation of wing-venation details impossible.

\section{Sclerogibbodes, new genus}

Type Species: Sclerogibbodes embioleia, new species.

Diagnosis: As for the subfamily (vide supra).

ETYMology: The new genus-group name is a combination of Sclerogibba (type genus of the family) and -odes (Gr., suffix meaning "looking like"). The name is feminine.

Comments: At present, the genus contains a single species occurring in Early Cretaceous (Neocomian) amber from Lebanon (table 1).

\section{Sclerogibbodes embioleia, new species}

Figures 1-2

Diagnosis: As for the genus (vide supra).

DESCRIPTION: As in those characters provided in the diagnosis for the subfamily, with the following additions: Female. Total body length $2.29 \mathrm{~mm}$; apparent forewing length $1.2 \mathrm{~mm}$ (measured along leading edge that is visible just beyond the body of the insect). Head length $0.47 \mathrm{~mm}$, width $0.36 \mathrm{~mm}$. Frontal prominence strongly pronounced, head tapering strongly beyond lower tangent of compound eyes. Compound eye with short, scattered setae; inner margins of compound eyes widely separated, separated by distance slightly less than compound eye length.
Antenna with 14 antennomeres, flagellomeres of approximately same shape except distal two flagellomeres distinctly wider than long; apex of distalmost flagellomere tapering. Mesosoma elongate and narrow, approximately three times as long as wide. Profemur greatly swollen, width slightly more than three times protibial width. Metasoma narrow (sting extruded in holotype: fig. 2). Integument black and appearing imbricate except antennae and tarsi dark brown; body with scattered short setae, those of mesosoma and metasoma arising from setigerous punctures; wings hyaline. Male. Unknown.

Holotyp: Female, Lebanese amber (Early Cretaceous: Neocomian). Deposited in the Amber Collection, Division of Invertebrate Zoology, American Museum of Natural History, New York.

ETYMOLOGY: The specific epithet is a combination of embios (Gr., meaning "lively"; origin of Embia, type genus of the webspinner order Embiodea) and lestes (Gr., meaning "plunderer"). The name is a reference to the obligate parasitism of embiodeans by this family of wasps.

\section{DISCUSSION}

As already noted, Sclerogibbodes is the sole fossil known for the family thereby extending the lineage back at least 125 million years. This age is intuitively pleasing because of the phylogenetic position of Sclerogibbidae as the extant sister group to the Dryinidae + Embolemidae lineage (Carpenter, 1986, 1999; Brothers, 1999; Brothers and Carpenter, 1993). Given the well-documented occurrence of dryinids and embolemids in the Cretaceous (Rasnitsyn, 1975, 1996; Ponomarenko, 1981a, 1981b; Olmi, 1998; Engel, 2003, 2005), it follows that Sclerogibbidae must be of a similar age. Indeed, most chrysidoid families extend well into the Early Cretaceous, with the sole exception of Plumariidae. Plumariidae are presently unknown from the fossil record, ${ }^{3}$ but given that they are the adelphotaxon of all other Chrysidoidea, their lineage was un-

\footnotetext{
${ }^{3}$ The Late Cretaceous amber plumariid reported by Grimaldi et al. (2000) appears to belong to an extinct family between Plumariidae and Scolebythidae (D.J. Brothers, personal commun.).
} 


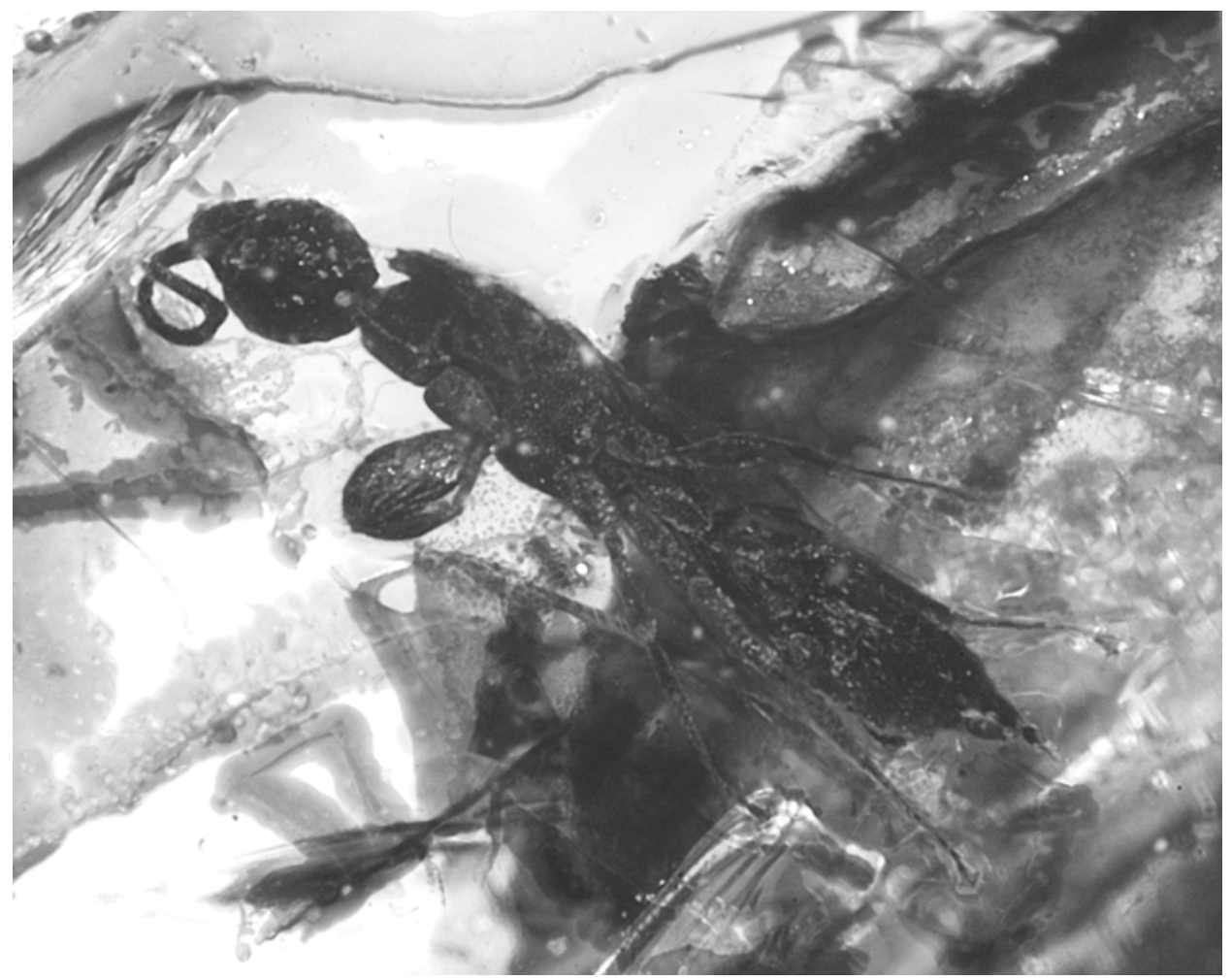

Fig. 1. Photomicrograph of holotype female of Sclerogibbodes embioleia (AMNH), new genus and species.

doubtedly present in the earliest Cretaceous as well. The exploration of amber deposits throughout the world is imperative for additional material of this family. The hosts of sclerogibbids (i.e., Embiodea) are similarly rare in the fossil record. Webspinner fossils have been recovered from the mid-Cretaceous amber of Myanmar (Cockerell, 1919; Davis, 1939; Grimaldi et al., 2002; Engel and Grimaldi, 2006), Eocene Baltic amber (e.g., Ross, 1956), Miocene Dominican amber (Szumik, 1994, 1998), as well as a compression fossil from the Eocene-Oligocene boundary of Florissant, Colorado (Cockerell, 1908; Ross, 1984). As discussed elsewhere the midCretaceous Embiodea are not basal members of the order and the origin and radiation of the group must have been significantly earlier (Grimaldi et al., 2002; Engel and Grimaldi, 2006). The embiodeans in Burmese amber have swollen probasitarsi, indicating that the mid-Cretaceous is a minimal age for the habit of constructing silken galleries. In lieu of a Lebanese amber webspinner the presence of Sclerogibbodes further strengthens the notion that Embiodea were present in the Early Cretaceous (and likely even earlier: vide Engel and Grimaldi, 2000; Grimaldi and Engel, 2005). The earliest age of Sclerogibbidae is constrained by the earliest aculeates/stem-group aculeates (Bethylonymidae: latest Jurassic).

The galleries of webspinners impose some physical constraints on the construction of wings for Embiodea, and thereby for sclerogibbids as well. Most Embiodea are apterous or shed their wings, thereby avoiding complications by which wings become entangled or damaged by gallery fibers. However, Embiodea have developed an intriguing evolutionary novelty allowing alates to move through their galleries unhindered. The wings of Embiodea are collapsible, allowing them the flexibility to bend when the webspinner reverses in a tunnel. A series of blood sinuses allow the wings to be filled by turgor pressure 


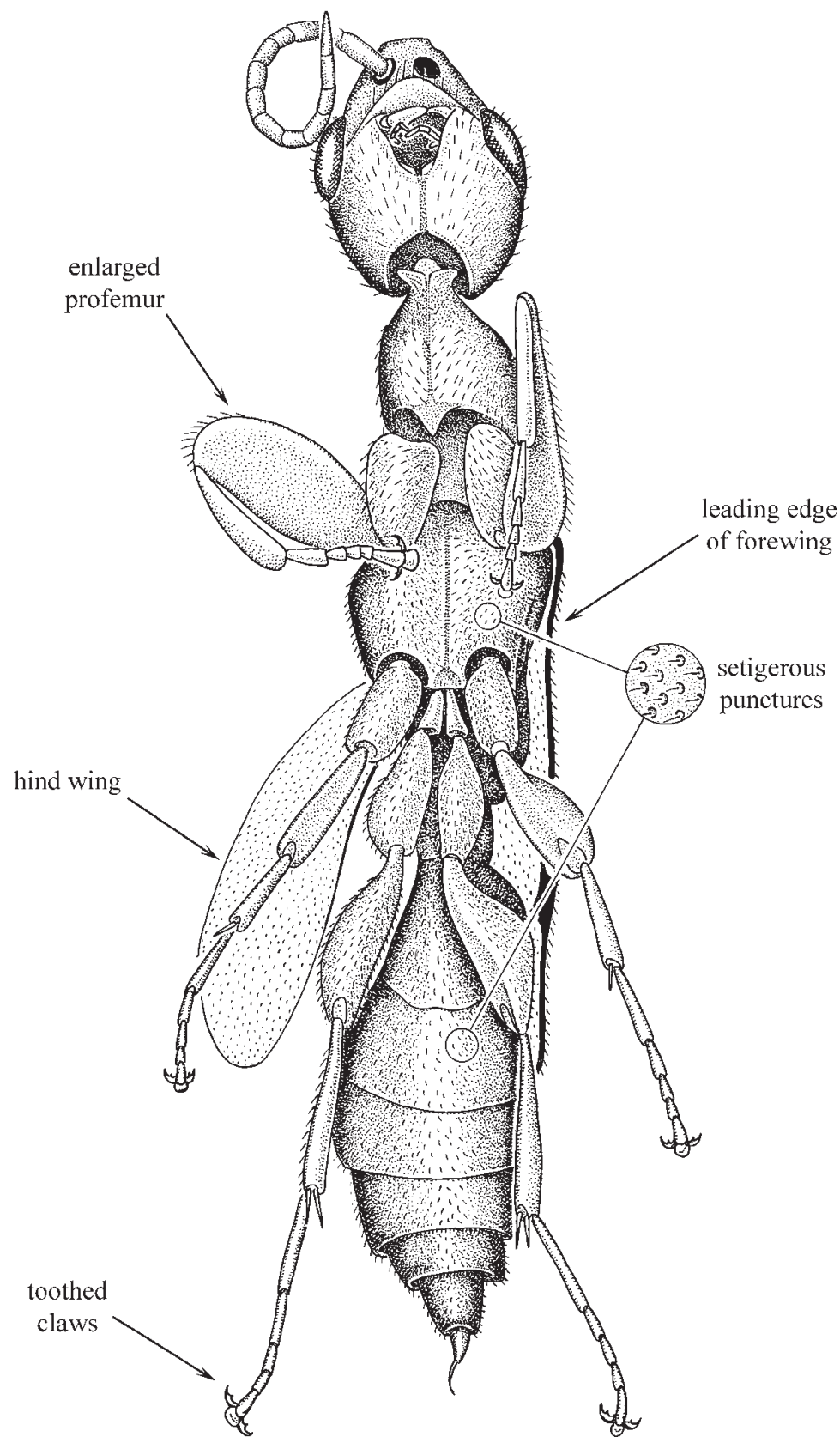

Fig. 2. Ventral habitus of Sclerogibbodes embioleia (AMNH), new genus and species.

once the gallery has been exited, thereby producing a more rigid structure that is useful, albeit in a limited capacity, as a flight foil. Just as it is for the natural occupants, reversing in the tunnels for the parasitoid is hampered by wings. Aptery in modern sclerogibbids pre- sumably aids females who enter the silken galleries to oviposit and then must eventually retreat from the nests. The plesiomorphic presence of wings in the female of Sclerogibbodes is thus of great significance. Their presence may indicate that Sclerogibbodes was 
an ectoparasitoid of some other lineage of insects (perhaps of wood-boring beetles as is generally primitive for Aculeata and other parasitoid lineages), and that the specialization on Embiodea had not yet occurred. Alternatively, Embiodea may have constructed looser, more vulnerable webs in the Early Cretaceous. For now, however, we do not consider the simple presence of wings to preclude the possibility that Sclerogibbodes was a parasitoid of webspinners like its modern relatives.

\section{ACKNOWLEDGMENTS}

Support was provided by Kansas Technology Enterprise Corporation/Kansas NSF EPSCoR grant KAN29503 (to MSE) and NSF EF-0341724 (to MSE) while NSF grant DBI-9987372 (to DAG) generously supported work on fossil insects in the AMNH. We are indebted to Michael Ohl and an anonymous reviewer for providing thorough and detailed critiques of the manuscript. This is contribution No. 3436 of the Division of Entomology, Natural History Museum, University of Kansas.

\section{REFERENCES}

Argaman, Q. 1988. Generic synopsis of Sclerogibbidae (Hymenoptera). Annales HistoricoNaturales Musei Nationalis Hungarici 80: 177-187.

Argaman, Q. 1993. A taxonomic study of Sclerogibbidae especially from the circumsardinian islands. Annali del Museo Civico di Storia Naturale "Giacomo Doria" 89: 537-553.

Ashmead, W.H. 1902. Classification of the fossorial, predaceous and parasitic wasps, or the superfamily Vespoidea. Canadian Entomologist 34: 268-273.

Brothers, D.J. 1999. Phylogeny and evolution of wasps, ants and bees (Hymenoptera, Chrysidoidea, Vespoidea and Apoidea). Zoologica Scripta 28: 233-249.

Brothers, D.J., and J.M. Carpenter. 1993. Phylogeny of Aculeata: Chrysidoidea and Vespoidea (Hymenoptera). Journal of Hymenoptera Research 2: 227-304.

Callan, E.McC. 1939. A note on the breeding of Probethylus callani Richards (Hymenopt., Bethylidae), an embiopteran parasite. Pro- ceedings of the Royal Entomological Society, London 8: 223-224.

Carpenter, J.M. 1986. Cladistics of the Chrysidoidea (Hymenoptera). Journal of the New York Entomological Society 94(3): 303-330.

Carpenter, J.M. 1999. What do we know about chrysidoid (Hymenoptera) relationships? Zoologica Scripta 28: 215-231.

Cockerell, T.D.A. 1908. Descriptions of Tertiary insects. II. American Journal of Science, series 4, 25: 227-232.

Cockerell, T.D.A. 1919. Two interesting insects in Burmese amber. Entomologist 52: 193-195.

Davis, C. 1939. Taxonomic notes on the order Embioptera. III. The genus Burmitembia Cockerell. Proceedings of the Linnean Society of New South Wales 64: 369-372.

Engel, M.S. 2003. An anteonine wasp in Cenomanian-Albian amber from Myanmar (Hymenoptera: Dryinidae). Journal of the Kansas Entomological Society 76(4): 616-621.

Engel, M.S. 2005. A dryinine wasp in Burmese amber (Hymenoptera: Dryinidae). Polskie Pismo Entomologiczne 74(4): 485-494.

Engel, M.S., and D.A. Grimaldi. 2000. A winged Zorotypus in Miocene amber from the Dominican Republic (Zoraptera: Zorotypidae), with discussion on relationships of and within the order. Acta Geologica Hispanica 35: 149-164.

Engel, M.S., and D.A. Grimaldi. 2006. The earliest webspinners (Insecta: Embiodea). American Museum Novitates 3514: 1-14.

Grimaldi, D., and M.S. Engel. 2005. Evolution of the insects. Cambridge: University Press, xv + $755 \mathrm{pp}$.

Grimaldi, D., A. Shedrinsky, and T.P. Wampler. 2000. A remarkable deposit of fossiliferous amber from the Upper Cretaceous (Turonian) of New Jersey. In D. Grimaldi (editor), Studies on fossils in amber, with particular reference to the Cretaceous of New Jersey: 1-76. Leiden, the Netherlands: Backhuys Publishers, xiii + $498 \mathrm{pp}$.

Grimaldi, D.A., M.S. Engel, and P.C. Nascimbene. 2002. Fossiliferous Cretaceous amber from Myanmar (Burma): Its rediscovery, biotic diversity, and paleontological significance. American Museum Novitates 3361: 1-72.

Olmi, M. 1998 [2000]. New fossil Dryinidae from Baltic and Lebanese amber (Hymenoptera Chrysidoidea). Frustula Entomologica 21: 48-67.

Ponomarenko, A.G. 1981a. New Dryinidae (Hymenoptera) from the Late Cretaceous of Taimyr and Canada. Paleontologischeskiy Zhurnal 1981: 139-143. [In Russian]

Ponomarenko, A.G. 1981b. New Dryinidae (Hymenoptera) from the Late Cretaceous of 
Taimyr and Canada. Paleontological Journal 15: 115-120. [Translation of Ponomarenko, 1981a]

Rasnitsyn, A.P. 1975. Hymenoptera-Apocrita of the Mesozoic. Trudy Paleontologicheskogo Instituta Akademii Nauk SSSR. [Transactions of the Paleontological Institute, Academy of Sciences USSR] 147: 1-132. [In Russian]

Rasnitsyn, A.P. 1996. New early Cretaceous Embolemidae $($ Vespida $=$ Hymenoptera: Chrysidoidea). Memoirs of the Entomological Society of Washington 17: 183-187.

Riek, E.F. 1970. Hymenoptera [excluding Apoidea and Formicidae]. In D.F. Waterhouse (editor), The insects of Australia: a textbook for students and research workers: 867-943. Melbourne: Melbourne University Press, xiii +1029 pp.

Ross, E.S. 1956. A new genus of Embioptera from Baltic amber. Mitteilungen aus dem Geologischen Staatsinstitut in Hamburg 25: 76-81.
Ross, E.S. 1984. A synopsis of the Embiidina of the United States. Proceedings of the Entomological Society of Washington 86(1): 82-93.

Ross, E.S. 2000. EMBIA: Contributions to the biosystematics of the insect order Embiidina. Part 2: A review of the biology of Embiidina. Occasional Papers of the California Academy of Sciences 149: 1-36.

Szumik, C.A. 1994. Oligembia vetusta, a new fossil teratembiid (Embioptera) from Dominican amber. Journal of the New York Entomological Society 102(1): 67-73.

Szumik, C.A. 1998. Una nueva especie de Anisembiidae (Insecta, Embioptera) en ámbar dominicano. Revista Brasileira de Entomologia 42(1-2): 7-8.

Yokoyama, A., and M. Tsuneyoshi. 1958. Discovery of a hymenopterous ectoparasite of Oligotoma japonica Okajima (Embioptera). Kontyû 26: 25-28. 